\title{
Inhibition of Cytosolic Phospholipase A2 $\alpha$ Induces Apoptosis in Multiple Myeloma Cells
}

\author{
Nur Mahammad ${ }^{1, *}$, Felicity J. Ashcroft ${ }^{1}$, Astrid J. Feuerherm ${ }^{1}$, Samah Elsaadi ${ }^{2}{ }^{\circledR}$, Esten N. Vandsemb ${ }^{2}$, \\ Magne Børset ${ }^{2,3}$ a and Berit Johansen ${ }^{1, *}$ \\ 1 Department of Biology, Norwegian University of Science and Technology (NTNU), 7491 Trondheim, Norway; \\ felicity.ashcroft@ntnu.no (F.J.A.); astrid.j.feuerherm@ntnu.no (A.J.F.) \\ 2 Center for Myeloma Research, Department of Clinical and Molecular Medicine, Faculty of Medicine and \\ Health Science, Norwegian University of Science and Technology (NTNU), 7491 Trondheim, Norway; \\ samah.elsaadi@ntnu.no (S.E.); esten.vandsemb@ntnu.no (E.N.V.); magne.borset@ntnu.no (M.B.) \\ 3 Department of Immunology and Transfusion Medicine, St. Olav's University Hospital, \\ 7491 Trondheim, Norway \\ * Correspondence: nurm@ntnu.no (N.M.); berit.johansen@ntnu.no (B.J.)
}

Citation: Mahammad, N.; Ashcroft, F.J.; Feuerherm, A.J.; Elsaadi, S.;

Vandsemb, E.N.; Børset, M.; Johansen, B. Inhibition of Cytosolic Phospholipase A2 $\alpha$ Induces Apoptosis in Multiple Myeloma Cells. Molecules 2021, 26, 7447. https:// doi.org/10.3390/molecules26247447

Academic Editor: Gabriella Marucci

Received: 1 November 2021

Accepted: 30 November 2021

Published: 9 December 2021

Publisher's Note: MDPI stays neutral with regard to jurisdictional claims in published maps and institutional affiliations.

Copyright: (C) 2021 by the authors. Licensee MDPI, Basel, Switzerland. This article is an open access article distributed under the terms and conditions of the Creative Commons Attribution (CC BY) license (https:// creativecommons.org/licenses/by/ $4.0 /)$.

\begin{abstract}
Cytosolic phospholipase $\mathrm{A} 2 \alpha(\mathrm{cPLA} 2 \alpha)$ is the rate-limiting enzyme in releasing arachidonic acid and biosynthesis of its derivative eicosanoids. Thus, the catalytic activity of cPLA2 $\alpha$ plays an important role in cellular metabolism in healthy as well as cancer cells. There is mounting evidence suggesting that cPLA2 $\alpha$ is an interesting target for cancer treatment; however, it is unclear which cancers are most relevant for further investigation. Here we report the relative expression of cPLA $2 \alpha$ in a variety of cancers and cancer cell lines using publicly available datasets. The profiling of a panel of cancer cell lines representing different tissue origins suggests that hematological malignancies are particularly sensitive to the growth inhibitory effect of cPLA2 $\alpha$ inhibition. Several hematological cancers and cancer cell lines overexpressed cPLA2 $\alpha$, including multiple myeloma. Multiple myeloma is an incurable hematological cancer of plasma cells in the bone marrow with an emerging requirement of therapeutic approaches. We show here that two CPLA2 $\alpha$ inhibitors AVX420 and AVX002, significantly and dose-dependently reduced the viability of multiple myeloma cells and induced apoptosis in vitro. Our findings implicate cPLA2 $\alpha$ activity in the survival of multiple myeloma cells and support further studies into cPLA2 $\alpha$ as a potential target for treating hematological cancers, including multiple myeloma.
\end{abstract}

Keywords: cPLA2 $\alpha$; PLA2G4A; cPLA2 $\alpha$ inhibitor; AVX002; AVX420; multiple myeloma; JJN3; IH1; RPMI8226; INA6; apoptosis

\section{Introduction}

Hematologic malignancies, which are cancers of the blood, bone marrow, and lymph nodes, account for approximately $8 \%$ of all cancers [1]. Among them, Multiple Myeloma $(\mathrm{MM})$, characterized by the aggregation of clonal, cancerous plasma cells in the bone marrow, accounts for about $10 \%$ of all hematological malignancies [1,2]. It evolves from an asymptomatic premalignant stage termed "monoclonal gammopathy of undetermined significance (MGUS)" and is associated with the overproduction of a monoclonal immunoglobulin or M protein in blood and urine [3]. Multiple myeloma generally affects elderly patients ( $>65$ years) with a median age at diagnosis of 70 years [4]. While newer treatments including thalidomide, lenalidomide (mechanism still under investigation), and proteasome inhibitors (e.g., bortezomib) have been developed during the past 15-20 years, chemotherapy in combination with steroids remains the major treatment for newly diagnosed multiple myeloma. The response rate is high, but all the patients eventually relapse [5,6]. Since multiple myeloma persists as cureless with high relapse frequency, a new therapeutic target could present possibilities for understanding the biology and treatment of the disease. 
The phospholipase A2 (PLA2) superfamily of enzymes are present in healthy and cancerous cells. They hydrolyze fatty acids from membrane phospholipids and can provide precursors for the biosynthesis of eicosanoids. Eicosanoids are biologically active lipids with clear roles in various pathological processes such as inflammation and cancer progression [7]. PLA2 enzymes are classified into six main groups: cytosolic and calcium-dependent PLA2 (cPLA2), calcium-independent PLA2 (iPLA2), secreted PLA2 (sPLA2), platelet-activating factor acetyl-hydrolase (PAF-AH), lysosomal PLA2 (lys-PLA2) and adipose PLA2 (Ad PLA2) [8]. cPLA2 $\alpha$ is the sole member of the group that shows high selectivity towards phospholipids carrying arachidonic acid (AA) at the $S n-2$ position leading to the release of AA, which serves as the precursor molecule in the biosynthesis of eicosanoids, including prostaglandins (PGs), thromboxanes (TXAs), leukotrienes (LTs), and lipoxins (LXs) [9]. The importance of eicosanoids in several disease settings makes cPLA2 $\alpha$ an interesting target for research.

Overexpression of the gene encoding cPLA2 $\alpha$ (PLA2G4A) has been reported in patient samples from different solid cancers such as breast cancer [10], hepatocellular carcinoma [11], cervical cancer [12], prostate cancer [13], and lung cancer [14], as well as hematological cancers such as acute myeloid leukemia (AML) $[15,16]$ and B-cell lymphocytic leukemia (B-CLL) [17]. Moreover, high gene expression of PLA2G4A has been correlated with poor patient outcomes, e.g., relapse, development of metastasis and lower survival, in cancers of lung, liver, and breast, glioblastoma, and multiple myeloma [18-22]. To our knowledge, the role of cPLA2 $\alpha$ in multiple myeloma has not however been investigated further.

As an attractive therapeutic target for chronic inflammatory diseases and cancers [23], several molecules have been developed to study or inhibit cPLA2 $\alpha$, and studies have shown that these inhibitors can reduce tumor growth and angiogenesis in solid tumors [24-26]. Arachidonyl trifluoromethyl ketone (AACOCF3), for example, was reported to sensitize tumors to radiation therapy via effects on the tumor vasculature [24] and was reported to inhibit the migration and invasion of lung cancer cells in vitro [27]. Another cPLA2 inhibitor, 4-[2-[5-chloro-1-(diphenylmethyl)-2-methyl-1H-indol-3-yl]-ethoxy]benzoic acid (CDIBA), has been used to demonstrate key regulatory roles of cPLA2 and lysophospholipids in brain and lung cancers in vivo [25], and cPLA2 $\alpha$ inhibitors (e.g., AVX001, AVX002, AVX235) developed by Avexxin, now Coegin Pharma, were previously shown to inhibit inflammation [28-33], tumor progression, and angiogenesis both in vitro and in vivo [34,35]. We previously reported that AVX001 and AVX002 were more potent than AACOCF3 in an in vitro CPLA2 $\alpha$ activity assay - where docosahexaenoic acid (22:6, n-3; DHA) was inactive [29]. In the current study, we used AVX002 and AVX420 (Methyl 2-(2-(4-heptyloxy)-phenoxy)-acetyl)thiazole-4-carboxylate) $[36,37]$ to investigate cPLA2 $\alpha$ as a potential target for treating the hematological cancer multiple myeloma.

\section{Results}

\section{1. cPLA2 $\alpha$ Is Overexpressed in Cancers and Cancer Cell Lines from Different Tissue Origins}

It is known that cPLA2 $\alpha$ can be overexpressed in cancer and involved in disease progression [10-17]; however, it is unclear how common this is and whether cancers originating from specific tissues may be more reliant on cPLA2 $\alpha$ than others. To get a better overview of whether certain cancers may be more reliant on cPLA2 $\alpha$ activity than others, we explored gene expression data from publicly available clinical cancer patient and cell line databases using Genevestigator and the Cancer Cell Line Encyclopedia (CCLE), respectively. Genevestigator is a new generation web-based tool that provides categorized quantitative information about genes and annotations contained in a large microarray database [38]. Analysis of 24,375 patient samples from cancers of 12 different tissue origins showed the highest expression of the gene encoding cPLA2 $\alpha$ (PLA2G4A) in cancers originating from the respiratory system and skin (Figure 1A). CCLE is a database composed of gene expression, gene copy number, and sequencing data from 947 human cancer cell lines [39]. Analysis of RNA-seq and copy number data using the CCLE showed 
that the PLA2G4A gene was most highly expressed in melanoma and certain leukemia and lymphoma cell lines, including acute myeloid leukemia (AML) and multiple myeloma (MM) (Figure 1B,C).

A.

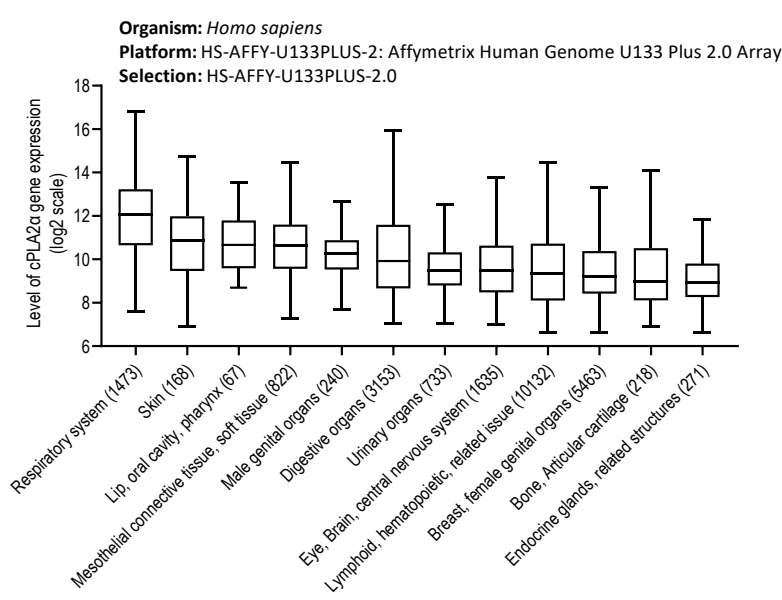

B.
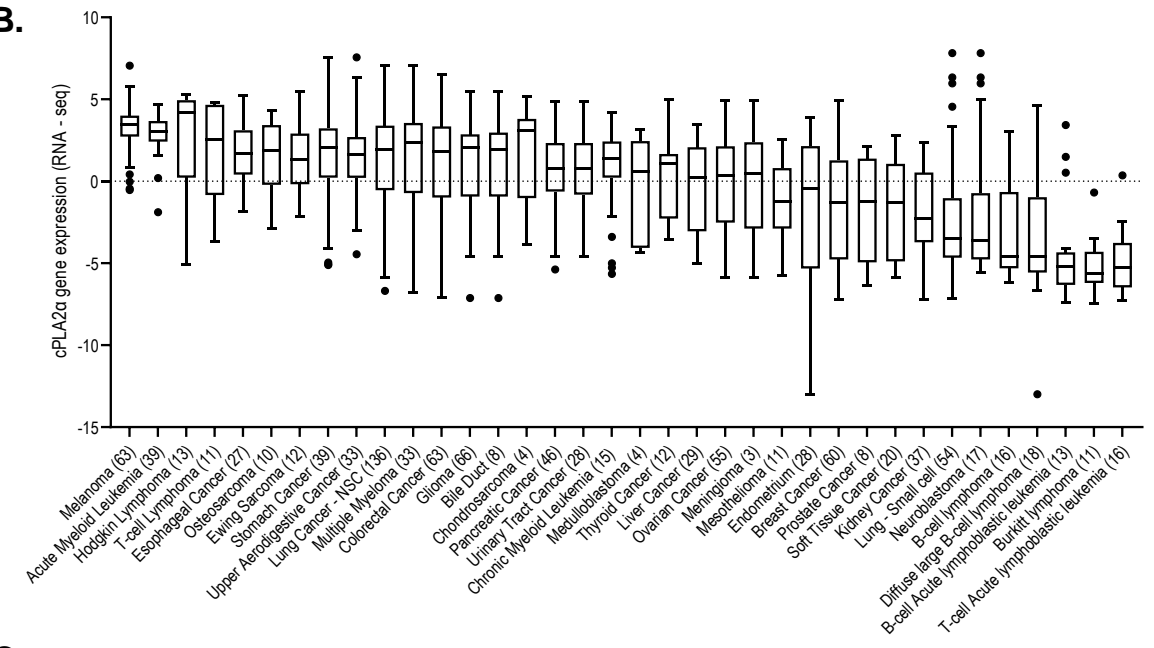

C.

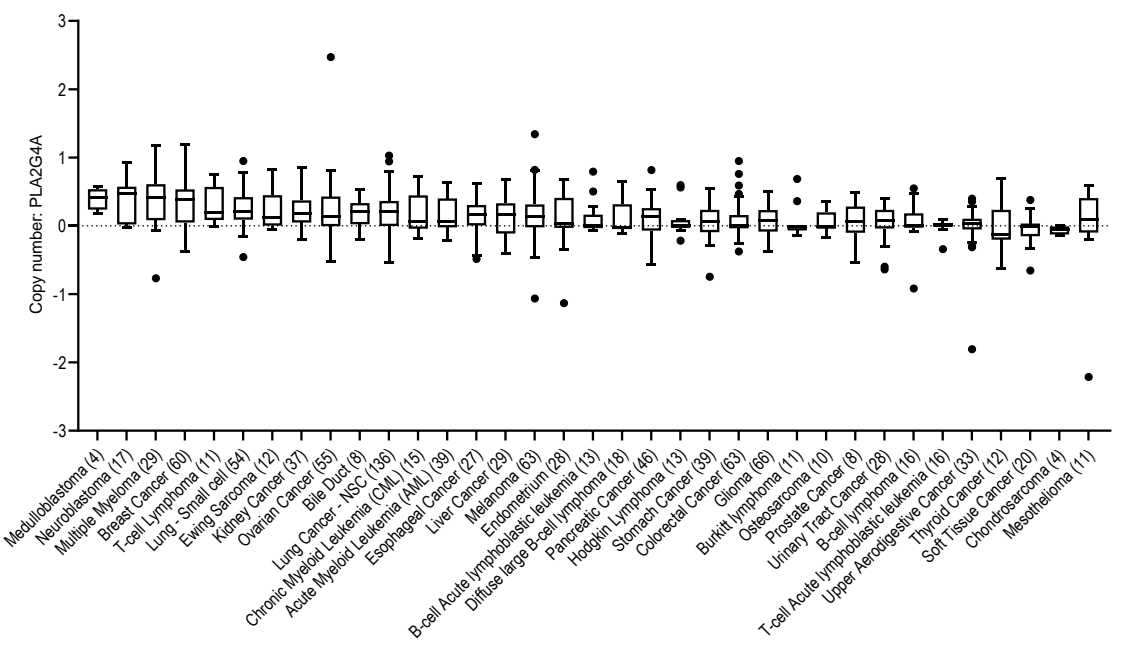

Figure 1. Comparative analysis of PLA2G4A gene expression in different cancers and cancer cell lines. (A) Relative expression of the PLA2G4A gene in 24,375 cancer patient samples grouped by tissue origin (collected from publicly available databases using Genevestigator). (B) Relative PLA2G4A gene expression (from RNAseq data) in solid and hematological cancer cell lines (collected from CCLE). (C) Copy number of the PLA2G4A gene in solid and hematological cancer cell lines (collected from CCLE). 


\subsection{Hematological Cancer Cells Are Sensitive to cPLA2 $\alpha$ Inhibition}

A second approach to investigate whether the origin of the cancer was a determinant of the importance of CPLA2 $\alpha$ in disease progression, was to determine the effect of cPLA $2 \alpha$ inhibition on the viability of a panel of 66 cancer cell lines (Oncolines panel); representing 14 different tissues of origin as shown in Figure 2A. The cPLA2 $\alpha$ inhibitors used in this study were AVX002, AVX235, and AVX420. We have previously published the anti-cancer properties of AVX235 in a basal-like breast cancer model [34,35] and reported the anti-inflammatory properties of AVX002 using both in vivo and cellular models [33]. AVX420 ((Methyl 2-(2-(4-heptyloxy)-phenoxy)-acetyl)thiazole-4-carboxylate) is structurally related to AVX235 (Methyl 2-(2-(4-octylphenoxy)-acetyl)thiazole-4-carboxylate) as opposed to AVX002, which is a derivative of omega-3 polyunsaturated fatty acid ( $\omega-3$ PUFA) [29,34]. Hematological cancer cell lines were highly sensitive to treatment with all the three cPLA2 $\alpha$ inhibitors, and this was the only group for whom the average IC50 was significantly different from the average for the entire panel (Figure 2C-E). The average IC50 values for solid cancers were $19.5 \mu \mathrm{M}, 16.3 \mu \mathrm{M}$, and $10.5 \mu \mathrm{M}$ for AVX420, AVX235, and AVX002, respectively. The average IC50 values were significantly lower in blood cancer cell lines, with IC50 values of $8.5 \mu \mathrm{M}, 11.9 \mu \mathrm{M}$, and $7 \mu \mathrm{M}$ for AVX420, AVX235, and AVX002, respectively (Figure 2B).

A.

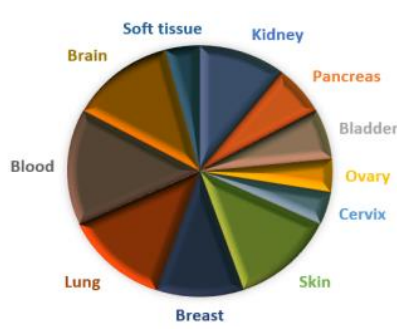

B.

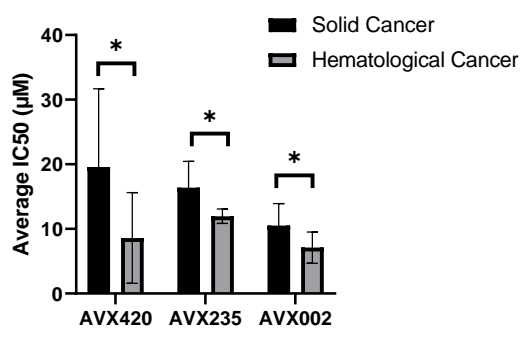

C.

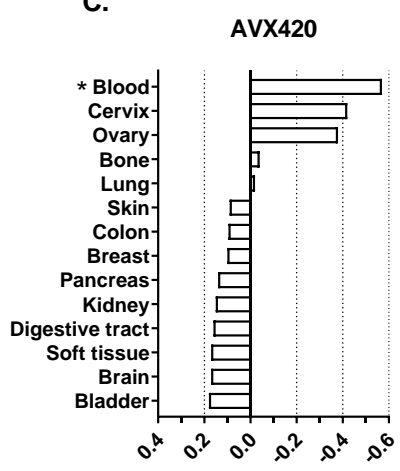

D.

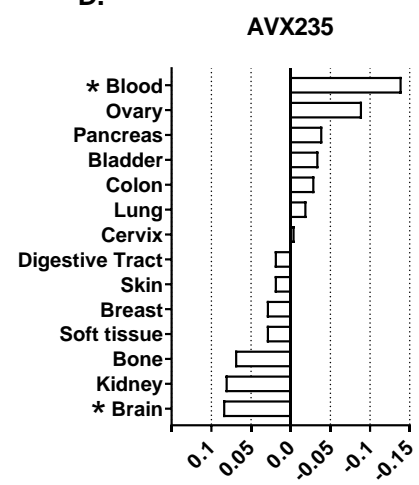

E.

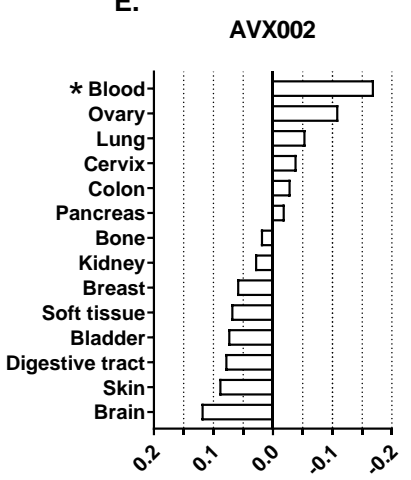

Figure 2. Cellular profiling of cPLA2 $\alpha$ inhibitors. (A) Tissue sources of the cell lines used in the Oncolines panel. (B) Average IC50 values of AVX420, AVX235, and AVX002 in solid versus blood cancer cell lines. To compensate for the violation of homogeneity of variances due to unequal sample sizes, the Welch ANOVA test was applied. ${ }^{*} p<0.05$. (C-E): Relative sensitivity of tissue type compared to the panel average is expressed in 10logIC50 for AVX420, AVX235, and AVX002. The chart depicts the average $10 \log$ IC50 values for each tissue type, containing at least two cell lines, relative to the average $10 \log$ IC50 measured in the entire panel. Tissue types represented by a single cell line (e.g., prostate, thyroid, uterus, etc.) were excluded from the analysis. A number of -1 on the horizontal axis, therefore, reflects a 10x lower IC50 compared to the panel average. The significance of the differences is determined with a t-test and considered significant if the $p$-value is less than 0.05 ; this is indicated with an asterisk. 


\section{3. cPLA2 $\alpha$ Is Overexpressed in Hematological Cancers including Multiple Myeloma}

Based on the finding that hematological cancer cell lines were more sensitive to cPLA2 $\alpha$ inhibition than solid cancer cell lines, we next explored PLA2G4A gene expression in different cancers of blood origin. Analysis of 10,131 hematological cancer patient samples showed the highest gene expression of PLA2G4A was in lymphoma, acute myeloid leukemia (AML), and multiple myeloma (MM) (Figure 3A). A separate analysis of the hematological cancer cell lines showed multiple myeloma had the highest PLA2G4A copy number (Figure $3 \mathrm{~B}$ ) and that the highest PLA2G4A gene expression was in acute myeloid leukemia (AML) lines (Figure 3C).

To compare the gene expression of PLA2G4A between cancer patients and healthy individuals, we used the cancer microarray database "Oncomine", which contains 65 gene expression datasets from over 4700 microarray experiments [40]. We found higher expression of PLA2G4A in multiple myeloma patients, as well as patients with the asymptomatic premalignant stage of multiple myeloma known as MGUS, in comparison to healthy individuals. There was approximately a 3 -fold increase in PLA2G4A gene expression in multiple myeloma and a 2.3-fold increase in MGUS patient samples (Figure 3D,E).

A.

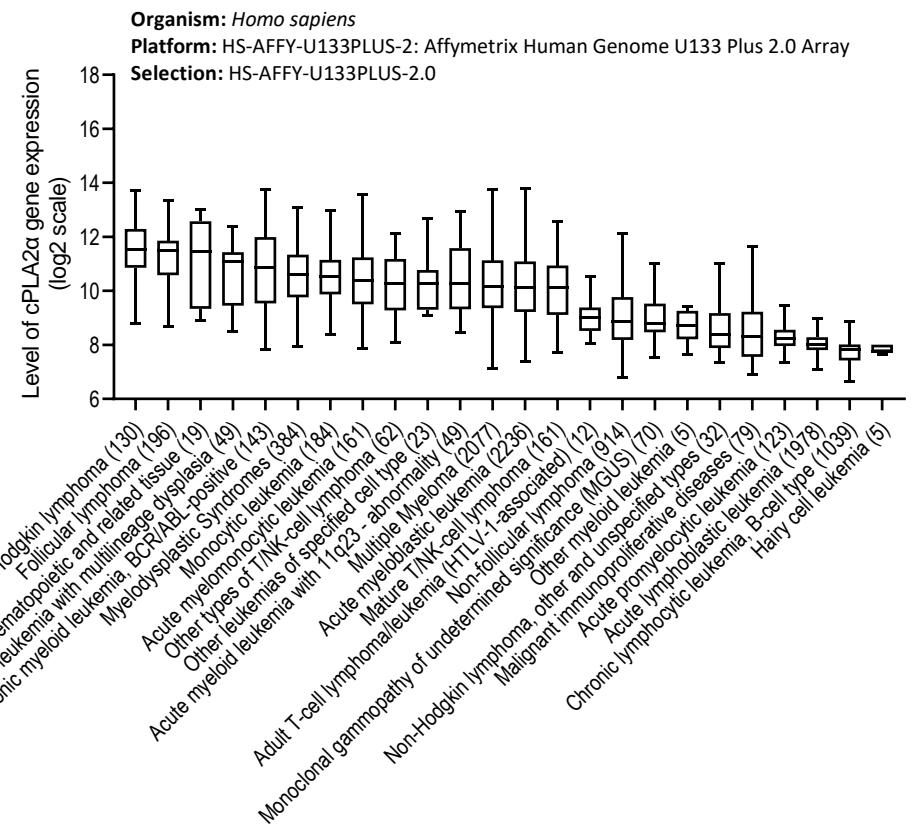

B.

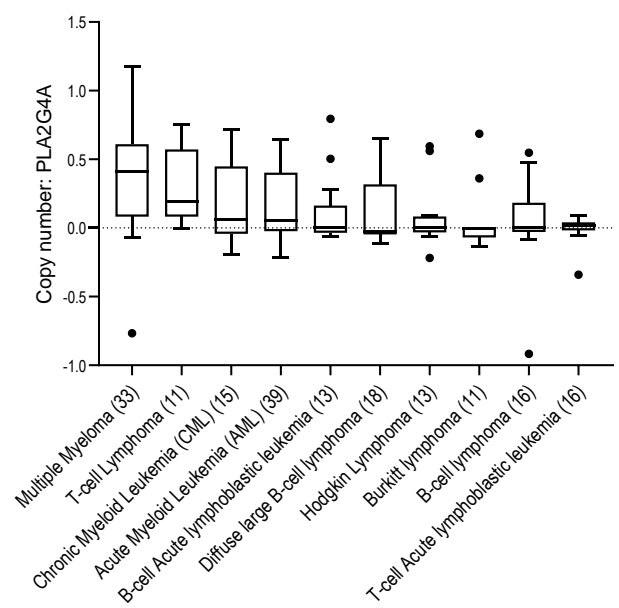

c.

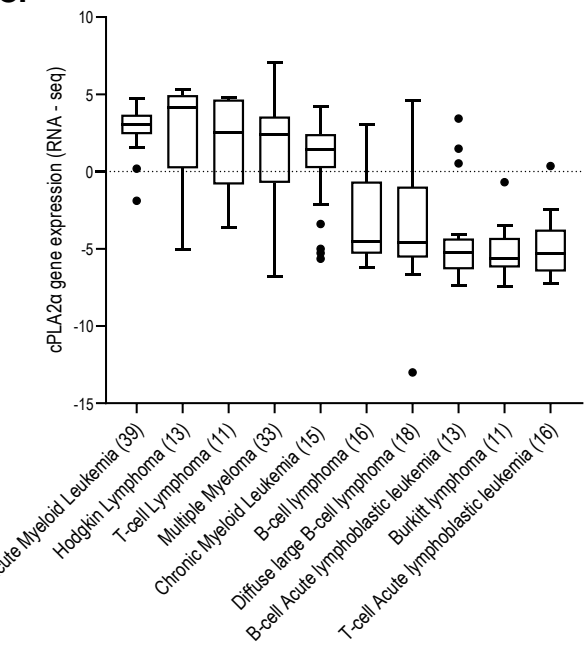

Figure 3. Cont. 
D.

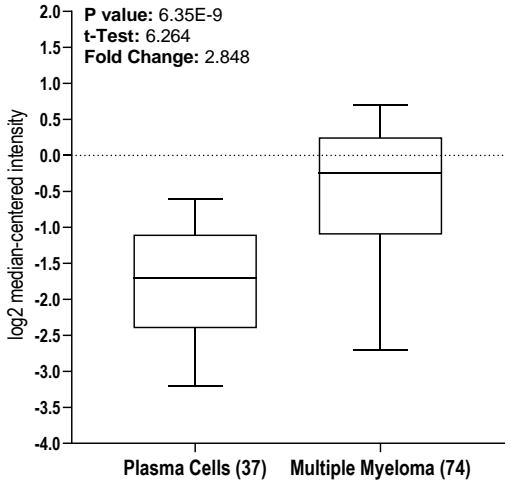

$\mathbf{F}$.

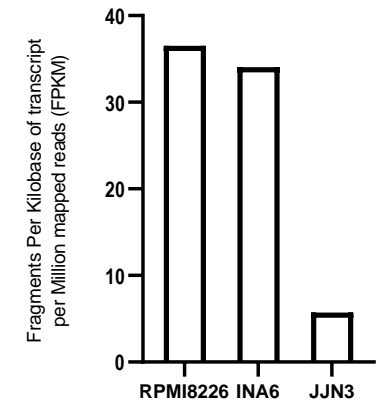

E.

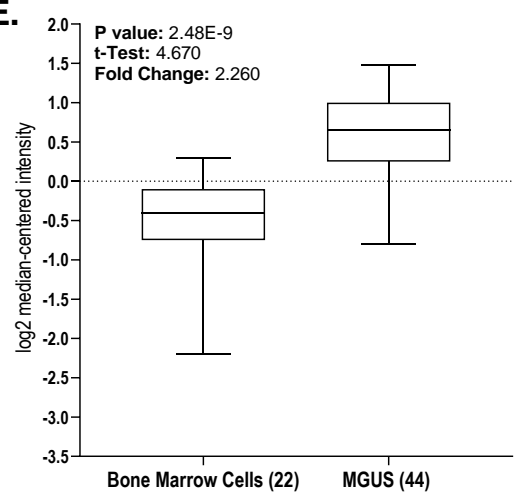

G.

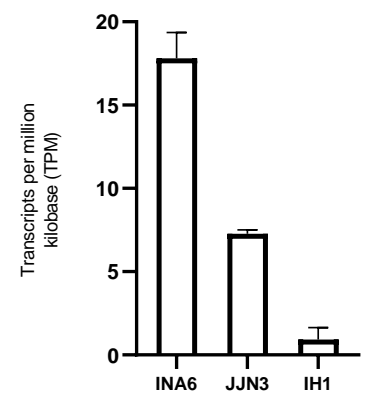

Figure 3. $P L A 2 G 4 A$ gene expression in hematological cancers. (A) PLA2G4A gene expression in 10,131 patient samples from more than 20 different lymphoid and hematopoietic cancer types (collected from publicly available databases using Genevestigator). (B) Copy number of PLA2G4A gene in hematological cancer cell lines (collected from CCLE). (C) PLA2G4A gene expression (RNAseq data) in hematological cancer cell lines (collected from CCLE). (D) PLA2G4A gene expression in 74 multiple myeloma patient samples compared to plasma cells from 37 normal individuals. (E) PLA2G4A gene expression in 44 monoclonal gammopathy of undetermined significance (MGUS) patient samples compared to bone marrow cells from 22 normal individuals. (F) PLA2G4A gene expression in three multiple myeloma cell lines (RPMI8226, INA6, and JJN3). Data was obtained from Jonathan Keats' lab (www.keatslab.org, accessed on 8 February 2021). (G) In-house screening of PLA2G4A gene expression in three multiple myeloma cell lines (INA6, JJN3, and IH1).

Together these results suggest that the growth of hematological cancers might be more sensitive to CPLA2 $\alpha$ inhibition than solid tumors. Overexpression of the PLA2G4A gene in multiple myeloma cell lines, and samples from patients with either symptomatic or asymptomatic myeloma, led us further to investigate the role of cPLA2 $\alpha$ in multiple myeloma using MM cell lines as models.

Based on RNA sequencing data obtained from Jonathan Keats' lab (www.keatslab.org, accessed on 8 February 2021) (Figure 3F) and our in-house screening (Figure 3G), four multiple myeloma cell lines (RPMI8226, INA6, IH1, and JJN3) were selected for further investigation. The cell lines RPMI8226 and INA6 had higher expression of the PLA2G4A gene than JJN3 and IH1 (Figure 3F,G).

\subsection{Inhibition of cPLA2 $\alpha$ Reduces Cell Viability of Multiple Myeloma Cells}

The effect of cPLA2 $\alpha$ inhibition on the viability of the four multiple myeloma cell lines was measured using two viability assays (Resazurin assay and Cell Titer Glo assay). AVX002 and AVX420 were used to inhibit cPLA2 $\alpha$; these chemically distinct CPLA2 $\alpha$ inhibitors had the highest efficacy (lowest IC50 values) in the Oncolines panel. Both inhibitors dose-dependently reduced the viability of all four cell lines, and comparable IC50 values were observed across both the viability assays (Figure 4). 
A.

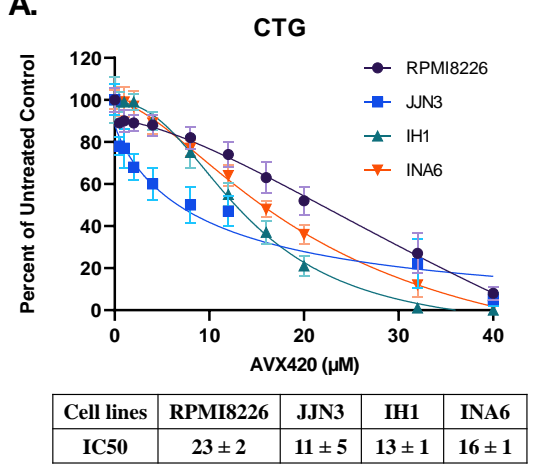

B.

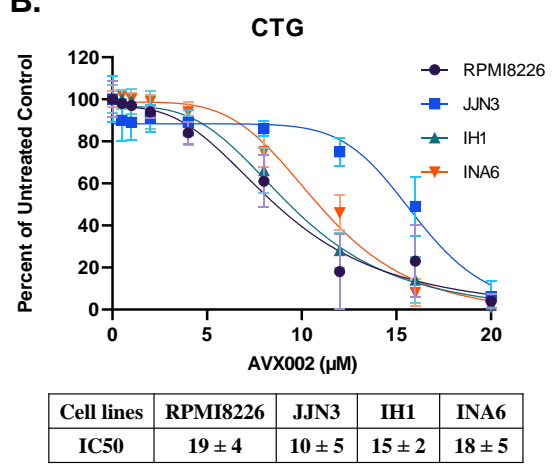

C.

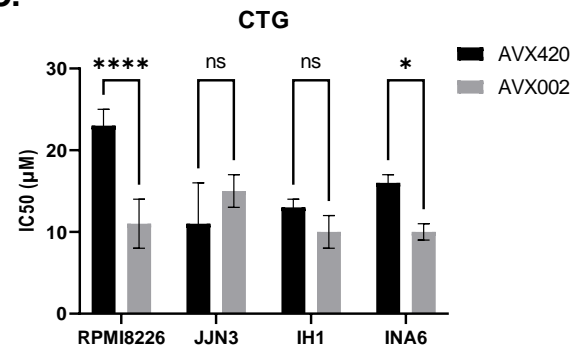

D.

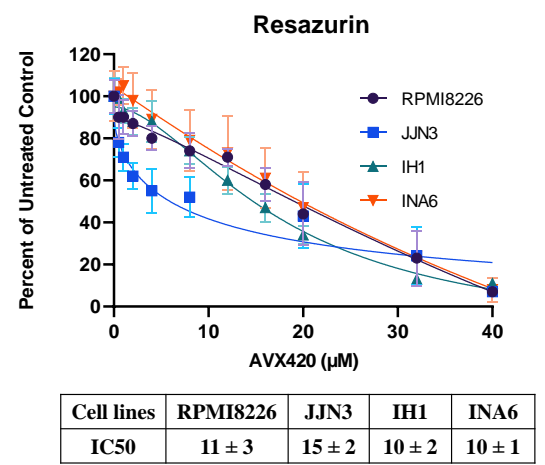

E.

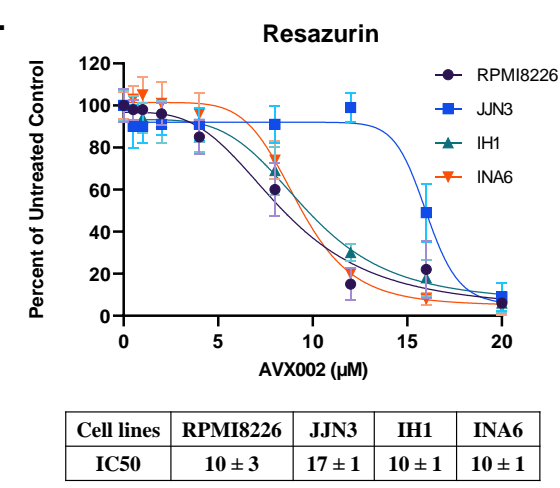

F.

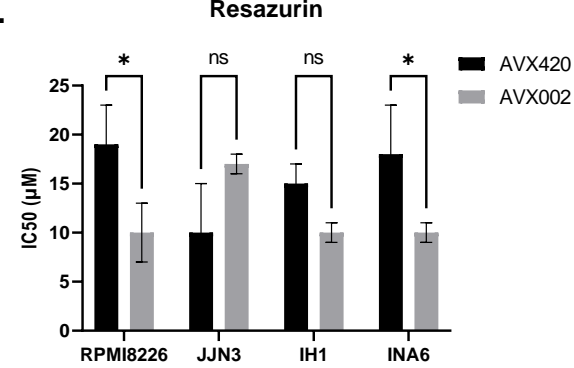

Figure 4. The effect of cPLA2 $\alpha$ inhibition on the viability of multiple myeloma cell lines. Cells were treated with the inhibitors (in the range of $0.5 \mu \mathrm{M}$ to $40 \mu \mathrm{M}$ ) for $72 \mathrm{~h}$ before cell titer Glo (CTG) and resazurin viability assays were performed. (A,B): Dose-response curves for AVX420 and AVX002 were measured using the CTG viability assay. (C) Comparison of IC50 values for AVX420 and AVX002 in RPMI8226, JJN3, IH1, and INA6 cells; measured using the CTG viability assay. (D,E): Dose-response curves for AVX420 and AVX002 were measured using the resazurin viability assay. (F) Comparison of IC50 values for AVX420 and AVX002 in RPMI8226, JJN3, IH1, and INA6 cells; measured using the resazurin viability assay. Data are presented as the mean \pm standard deviation, and each measurement was repeated at least three times independently. ${ }^{*} p<0.05,{ }^{* * * *} p<0.0001$, compared as indicated in the figures.

The sensitivity to AVX420 and AVX002 varied across cell lines (Figure 4C,F). RPMI8226 and INA6 cell lines, representing the high expression of the cPLA2 $\alpha$ gene (PLA2G4A), were significantly more sensitive to treatment with AVX002 than AVX420. There was no significant difference in sensitivity between AVX420 and AVX002 in the IH1 and JJN3 cells, although JJN3 cells tended to be more sensitive to AVX420. Collectively, these findings indicate that inhibition of $\mathrm{cPLA} 2 \alpha$ reduces the viability of multiple myeloma cells independent of the gene expression level. 


\section{5. cPLA2 $\alpha$ Inhibitors Induce Apoptosis in Caspase-3 Dependent Pathways}

Having shown that the cPLA2 $\alpha$ inhibitors, AVX420 and AVX002, reduced cell viability in a dose-dependent manner, we next wanted to investigate whether the reduced viability could be explained by apoptosis. Apoptosis was first measured using Annexin V-FITC (fluorescein isothiocyanate) staining. JJN3 cells were treated with cPLA2 $\alpha$ inhibitors for $72 \mathrm{~h}$ under serum-reduced conditions ( $4 \%$ serum). The percentage of living (Annexin V and propidium iodide negative), early apoptotic (Annexin $\mathrm{V}$ positive), and late apoptotic/dead cells (Annexin $\mathrm{V}$ and propidium iodide positive) are shown with representative density plots (Figure 5A). Treatment of JJN3 cells with $20 \mu \mathrm{M}$ of AVX420 or AVX002 significantly increased the numbers of early apoptotic and late apoptotic/dead cells in the population (Figure 5B).

A.

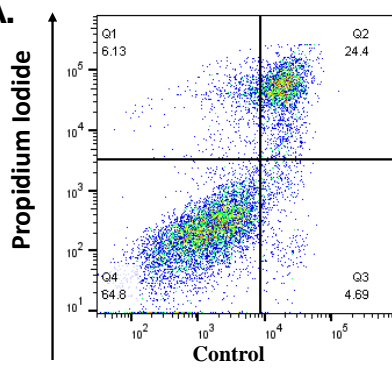

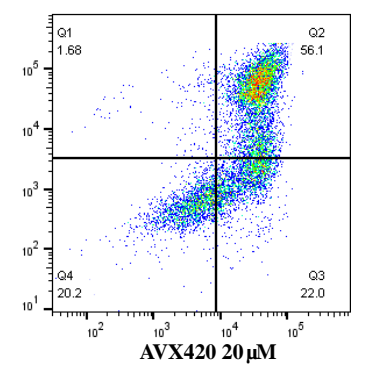

Annexin V

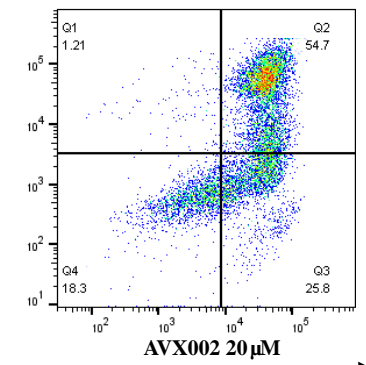

AVX002 20 $\mu \mathrm{M}$
B.

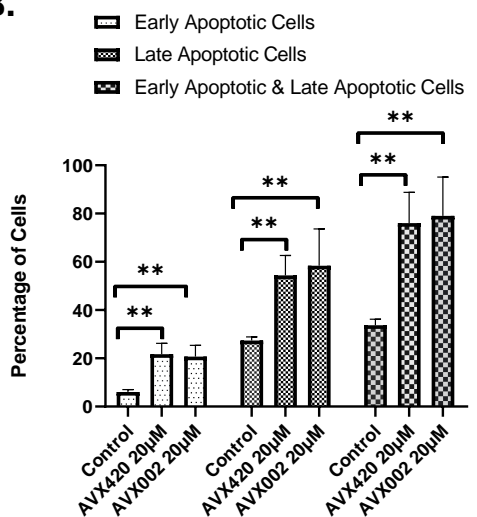

C. $6 \mathrm{H}$

$$
18 \mathrm{H}
$$$$
18 \mathrm{H}
$$

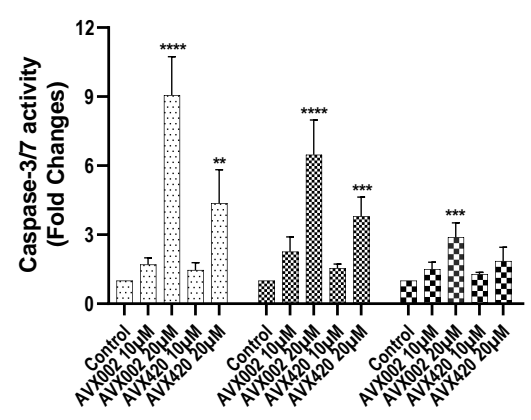

D.

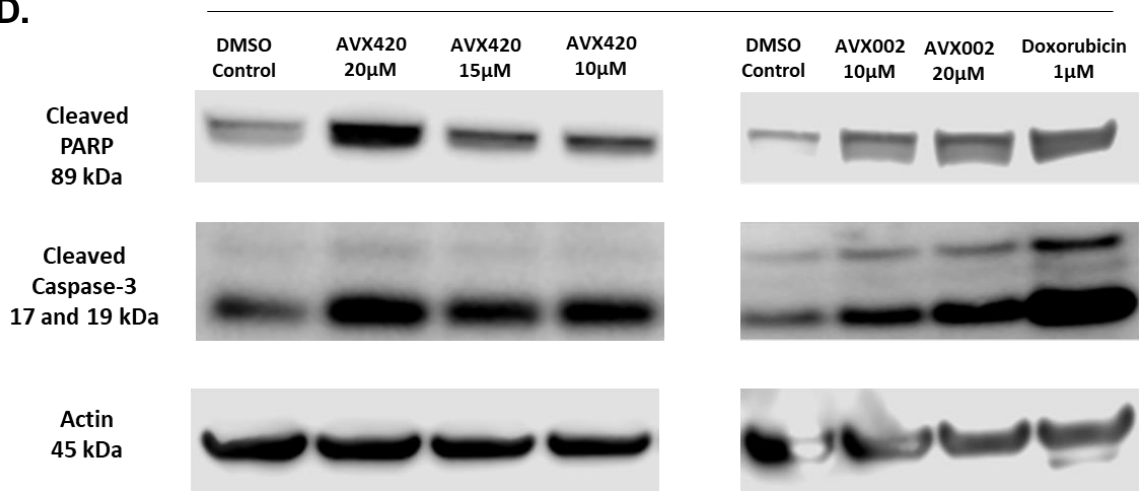

Figure 5. cPLA2 $\alpha$ inhibitors induce apoptosis in JJN3 cells. (A,B): The percentage of early apoptotic, late apoptotic/dead, and a combination of early and late apoptotic/dead cells after $72 \mathrm{~h}$ treatment with inhibitors as indicated. (C) Measurement of caspase-3/7 activity. Cells were treated with inhibitors as indicated or left untreated (control) for 6 h, 18 h, or 48 h, and caspase- $3 / 7$ activity was 
measured using the caspase-3/7 Glo assay. (D) Immunoblot analysis of apoptosis-related proteins after treatment with inhibitors for $36 \mathrm{~h}$. Data in $(\mathbf{B}, \mathbf{C})$ are presented as mean \pm standard deviation, and each measurement was repeated at least three times independently. ${ }^{* *} p<0.01,{ }^{* * *} p<0.001$, **** $p<0.0001$, compared with untreated control.

Since both extrinsic and intrinsic pathways of apoptosis converge to a common execution phase involving proteolysis and activation of caspase-3 and / or -7 (caspase-3/7), we next assayed for apoptosis by measuring the activation of caspase- $3 / 7$ using a specific substrate. JJN3 cells were treated with AVX420 or AVX002 for $6 \mathrm{~h}, 18 \mathrm{~h}$, and $48 \mathrm{~h}$. The cells showed significantly increased caspase-3/7 activity after treatment with $20 \mu \mathrm{M}$ AVX420 or AVX002 for $6 \mathrm{~h}$ or $18 \mathrm{~h}$ compared to the untreated control. A reduction in the activity of caspase-3/7 after $48 \mathrm{~h}$ could indicate the end of the early phase of apoptosis (Figure 5C).

Other early events in apoptosis include the cleavage of poly (ADP-ribose) polymerase (PARP) and caspase-3 [41-43]. We analyzed these events using immunoblotting and showed that following $36 \mathrm{~h}$ of treatment with $10 \mu \mathrm{M}$ of either inhibitor; there was an increased level of cleaved PARP and cleaved caspase-3 (Figure 5D). Doxorubicin was used as a positive control in the study, which is a well-established inducer of apoptosis in several other cancer cells [44-46].

Together, the results of the Annexin V apoptosis assay, caspase-3/7 activity assay, and immunoblots for cleaved caspase- 3 and PARP make it likely that the observed reduction in viability seen in multiple myeloma cells treated with cPLA2 $\alpha$ inhibitors is due to induction of apoptosis.

\section{Discussion}

In this study, we showed that cell lines of hematological origin were highly susceptible to the effects of cPLA2 $\alpha$ inhibition on cell viability. Multiple myeloma (MM) represented hematological cancer that overexpressed PLA2G4A, and we showed that two CPLA2 $\alpha$ inhibitors, AVX420 and AVX002, reduced viability in different multiple myeloma cell lines, likely via induction of apoptosis.

Our exploration of public data demonstrated higher expression of PLA2G4A in human cancers of specific tissue origins, including the respiratory system, skin, digestive organs, and urinary organs. This is consistent with previous studies in non-small cell lung carcinoma (NSCLC) [47], prostate cancer [13], cholangiocarcinoma (SG231) [48], and colon cancer [49]. We also found PLA2G4A to be highly expressed in certain hematological cancers, including acute myeloid leukemia (AML), which is consistent with the previous reports of overexpression of PLA2G4A in leukemias [15-17], and also in multiple myeloma and lymphoma, which has not previously been reported. We also found higher gene expression of PLA2G4A in both MM and MGUS patients than in healthy individuals, supporting $\mathrm{MM}$ as an interesting cancer for further investigation.

A growing body of evidence implicates cPLA2 $\alpha$ in the development or progression of solid [10-14] as well as hematological cancers [15-17] with roles demonstrated in cell proliferation [50-52], angiogenesis [24,25,34,53], and metastasis [27,35,54]. Here we show, for the first time, that the cPLA2 $\alpha$ inhibitor AVX002, for which only anti-inflammatory properties had previously been described [33], can also affect cell viability, and we report that a novel cPLA2 $\alpha$ inhibitor AVX420 had similar effects.

The viability of four cell lines was significantly reduced by cPLA2 $\alpha$ inhibitors AVX420 and AVX002, and we investigated whether the reduced viability was due to apoptosis. Structural modification of the plasma membrane with externalization of phosphatidylserine is an early indicator of apoptosis [55-57] and was detected in response to both the inhibitors. Since caspase- $3 / 7$ plays an essential role in the execution of apoptosis, increased activity of caspase-3/7 can also be used as an indicator of apoptotic cell death [58-60]. In our study, caspase-3/7 activity was significantly increased in CPLA2 $\alpha$ inhibitor-treated cells at early ( 6 and $18 \mathrm{~h}$ ) vs. later $(48 \mathrm{~h}$ ) timepoints. The reduction in caspase-3/7 activity after longer incubation periods that we observed in our study was also reported in a previous study by Terri Sundquist [61]. We also found increased levels of cleaved caspase-3 and cleaved 
PARP protein in cPLA2 $\alpha$ inhibitor-treated cells. These are hallmarks of apoptotic cell death, not occurring in necrosis, and this lends support to the hypothesis that cPLA2 $\alpha$ inhibitors can trigger apoptosis in multiple myeloma cells.

Our findings that the AVX002 and AVX420 can reduce the viability of multiple myeloma cells in vitro may be specific to the disease model because AVX235 and AVX002 showed surprisingly low adverse effects in our previous in vivo studies [33,34]. AVX235, which is closely related to AVX420, was tested in a mouse orthotopic xenograft model [34], and AVX002 was tested in both prophylactic and therapeutic collagen-induced arthritis models [33]. In both cases, the cPLA2 $\alpha$ inhibitors showed minimal side effects, supporting the potential for using these compounds therapeutically.

cPLA2 $\alpha$ inhibition can reduce the cellular production of PGE2 by decreasing the availability of arachidonic acid (AA), reducing the expression of genes encoding cyclooxygenase2 (COX-2) (PTGS2) and CPLA2 $\alpha$ (PLA2G4A) [30] and inhibiting the activity of the transcription factor nuclear factor kappa B(NFkB) [62]. This has well-known anti-inflammatory effects but can also affect cell survival and proliferation via inhibition of EP4-dependent $\mathrm{PI} 3 \mathrm{~K} / \mathrm{AKT}$ signaling [63] and the transcription factor forkhead box protein O1 (FOXO1) [50]. Based on these studies, we hypothesize that PGE2/EP4/PI3K signaling may be required for the survival of multiple myeloma cells, and thus inhibiting this pathway could result in cell cycle arrest and apoptosis, as summarized in Figure 6.

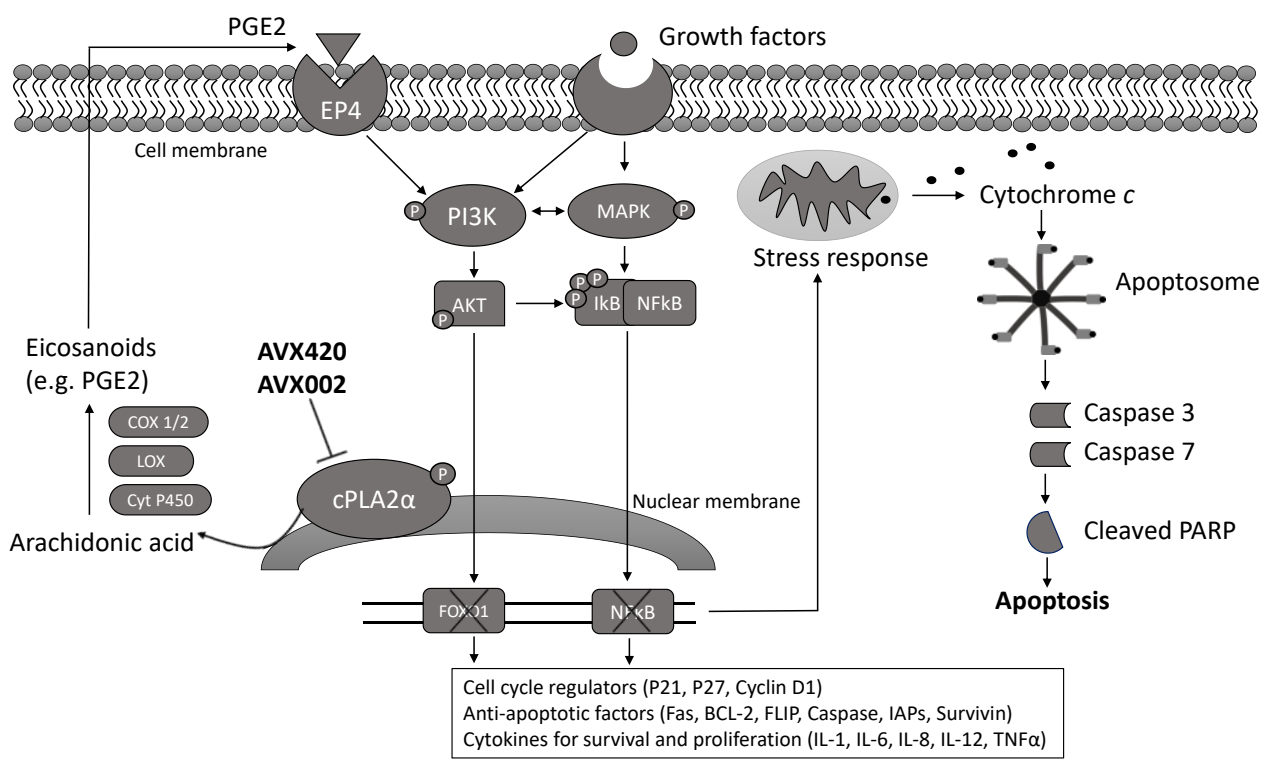

Figure 6. A hypothesized molecular mechanism demonstrates how CPLA2 $\alpha$ inhibition could reduce the viability of multiple myeloma cells. Growth factors (e.g., PDGF) are well known to activate MAPK and PI3K/AKT signaling pathways. This can cause the phosphorylation and activation of cPLA2 $\alpha$ resulting in the release of arachidonic acid and subsequent production of eicosanoids. PGE2 is one of the most studied eicosanoids, and it is known to bind to and activate the EP4 receptor. EP4 activation can stimulate the PI3K/AKT/FOXO1 and PI3K/AKT/NFKB signaling pathways associated with promoting cell survival and proliferation via regulating the expression of cell cycle proteins, anti-apoptotic factors, and cytokines. Thus, inhibition of cPLA $2 \alpha$ by AVX420 and AVX002 may inhibit the pathways that support cell survival and proliferation and cause cellular stress responses leading to the production of reactive oxygen species (ROS) and release of cytochrome $c$ from mitochondria, and ultimately the cleavage and activation of caspase- $3 / 7$ and PARP to execute apoptosis. PDGF, platelet-derived growth factor; MAPK, mitogen-activated protein kinase; cPLA2 $\alpha$, cytosolic phospholipase A2 $\alpha$; PGE2, prostaglandin E2; COX-1/2, cyclooxygenase-1 and -2; LOX, lipoxygenase; Cyt P450, cytochrome P450; EP4, E-type prostanoid receptor 4; PI3K, phosphatidyl inositol-3 kinase; AKT, protein kinase $B$; IkB, inhibitor of nuclear factor kappa B; NFKB, nuclear factor kappa B; FOXO1, forkhead box protein O1; PARP, poly (ADP-ribose) polymerase. 
Based on our findings, we conclude that cPLA2 $\alpha$ may have an important role in hematological cancers. Inhibition of cPLA $2 \alpha$ in multiple myeloma cells likely causes cell death by apoptosis, supporting its potential as a therapeutic target for the treatment of this disease.

\section{Materials and Methods}

\subsection{Materials}

Cell culture media, recombinant IL-6 (\#SRP3096) and dimethyl sulfoxide (DMSO) (\#2650) were purchased from Sigma-Aldrich (St. Louis, MO, USA). Antibodies were obtained from Cell Signaling Technology (Danvers, MA, USA) (e.g., cleaved PARP (CST \#5625), cleaved caspase-3 (CST \#9664) and $\beta$-Actin (CST \#4970)) and doxorubicin from Cayman Chemicals (Ann Arbor, MI, USA) (\#15007). AVX002 (1,1,1-trifluoro-3-(((3Z,6Z,9Z,12Z,15Z)octadeca-3,6,9,12,15-pentaen-1-yl)thio)propan-2-one) [64] and AVX235 (methyl 2-(2-(4octylphenoxy)acetyl)thiazole-4-carboxylate) [65] were synthesized by Synthetica AS, Oslo. AVX420 ((Methyl 2-(2-(4-heptyloxy)-phenoxy)-acetyl)thiazole-4-carboxylate) were synthesized in the laboratory of organic chemistry at University of Athens by George Kokotos [36]. AVX002, AVX235 and AVX420 were stored at $-80{ }^{\circ} \mathrm{C}$ in DMSO.

\subsection{Maintenance of Multiple Myeloma Cell Lines}

The human multiple myeloma cell lines (HMCL) were obtained from St. Olavs University hospital, Trondheim, Norway (IH1), American Type Culture Collection (ATCC) (Manassas, VA, USA) (RPMI8226), a gift from Dr. M Gramatzki, University of Erlangen Nuremberg, Erlangen, Germany (INA6), and Dr. I.M. Franklin, University of Birmingham, UK (JJN3).

All HMCL were maintained in RPMI 1640 supplemented with L-glutamine $(0.68 \mathrm{mM})$ and FBS. All cell lines were cultivated with 10\% FBS except RPMI8226 which was cultivated with $20 \% \mathrm{FBS}$ at $37^{\circ} \mathrm{C}$ with $5 \% \mathrm{CO}_{2}$ in a humidified atmosphere. IH1 and INA6 cells were always supplemented with IL-6 $(1 \mathrm{ng} / \mathrm{mL})$. New cells were routinely tested to ensure the absence of mycoplasma. Typically, HMCL were maintained in T-75 flasks and split twice per week.

\subsection{Viability Screening of Oncolines Cancer Cell Panel}

Cell viability in response to CPLA2 $\alpha$ inhibitors was investigated using the Oncolines cancer cell panel and performed and analyzed according to NTRC's (Netherlands Translational Research Center) methods described previously $(32,33)$ except for assaying under reduced serum conditions. In brief, cells were diluted in their ATCC-recommended medium and dispensed in a 384-well plate at a concentration of 200-3200 cells per well in $45 \mu \mathrm{L}$ medium. Plated cells were incubated in a humidified atmosphere of $5 \% \mathrm{CO}_{2}$ at $37^{\circ} \mathrm{C}$. After $24 \mathrm{~h}, 5 \mu \mathrm{L}$ of the cPLA $2 \alpha$ inhibitors with a dose range of $10 \mathrm{nM}$ to $100 \mu \mathrm{M}$ was added, and plates were incubated for another $72 \mathrm{~h}$. After $72 \mathrm{~h}, 25 \mu \mathrm{L}$ of ATPlite 1step ${ }^{\mathrm{TM}}$ (PerkinElmer, Waltham, MA, USA) solution was added to each well and subsequently shaken for $2 \mathrm{~min}$. After $10 \mathrm{~min}$ of incubation in the dark, the luminescence was recorded on an Envision multimode reader (PerkinElmer, Waltham, MA, USA).

\subsection{Cell Viability Assays}

Cells were harvested by centrifugation at $1500 \mathrm{rpm}$ for $8 \mathrm{~min}$. The supernatant was discarded, and the cells were resuspended in experimental media. The cell counter Countess ${ }^{\mathrm{TM}}$ was used to count the number of cells and check the viability by staining with trypan blue $(0.4 \%)$ (NanoEnTek, Waltham, MA, USA). Then, 10,000 cells were seeded in at least three technical replicates for both CTG (cell titer Glo assay) and resazurin assay in $100 \mu \mathrm{L}$ and treated as indicated before measurement of cell proliferation. CTG reagent was added according to the manufacturer's instructions and left to incubate for $10 \mathrm{~min}$, covered with aluminum foil to protect the reaction mix from light. Luminescence was determined using a Victor 1420 multilabel counter (PerkinElmer Inc. Waltham, MA, USA). 
Resazurin (RnD Systems, Abingdon, UK) was added according to the manufacturer's instructions and left to incubate for $2 \mathrm{~h}$ at $37^{\circ} \mathrm{C}$ with $5 \% \mathrm{CO}_{2}$ in a humidified atmosphere. Fluorescence was read at $544 \mathrm{~nm}$ excitation and $590 \mathrm{~nm}$ emission wavelengths using the Cytation 5 cell imaging multimode reader (Biotek Instruments, Winooski, VT, USA).

\subsection{Annexin V-FITC and Propidium Iodide Apoptosis Assay}

Annexin-V-fluorescein isothiocyanate (FITC) kit (Tau Technologies, Albuquerque, NM, USA) was used to determine apoptosis. Cells were harvested by centrifugation at $1500 \mathrm{rpm}$ for $8 \mathrm{~min}$. The supernatant was discarded, and the cells were resuspended in experimental media. The cell counter Countess ${ }^{\mathrm{TM}}$ was used to count the number of cells and check viability by staining with trypan blue ( $0.4 \%)$ (NanoEnTek, Waltham, MA, USA). For Annexin V-FITC and propidium iodide staining, 100,000 cells were seeded in 24-well flat-bottom plates. Cells were treated on the same day, and stimulated cells were incubated at $5 \% \mathrm{CO}_{2}, 37^{\circ} \mathrm{C}$ for $72 \mathrm{~h}$ before incubating them with Annexin V-FITC $(0.2 \mu \mathrm{g} / \mathrm{mL}$ in $1 \mathrm{X}$ Annexin binding buffer) for $1 \mathrm{~h}$ on ice. Propidium iodide $(1.4 \mu \mathrm{g} / \mathrm{mL})$ was added $5 \mathrm{~min}$ prior to data acquisition using an LSRII flow cytometer (BD Biosciences, San Jose, CA, USA). FlowJo Software v10.1 (Ashland, OR, USA) was used to analyze the data.

\subsection{Caspase-3/7 Activity Assay}

Caspase activity was measured using a Caspase-3/7 Glo assay kit (Promega Corporation, Madison, WI, USA). HMCL cells were seeded in 96-well white plates at a density of 10,000 cells per well. The cells were treated with inhibitors for $6 \mathrm{~h}, 18 \mathrm{~h}$, and $48 \mathrm{~h}$, then $50 \mu \mathrm{L}$ caspase- $3 / 7$ reagent was added to each well and incubated for $1 \mathrm{~h}$ at room temperature. The luminescence reading was then measured using the victor 1420 multilabel counter (Perkin Elmer Inc., Waltham, MA, USA).

\subsection{Western Blot}

To prepare the samples, the cells were washed with ice-cold phosphate-buffered saline (PBS), and lysis buffer (1\% of IGEPAL $® C A-630$ (Sigma-Aldrich, St. Louis, MO, USA), $150 \mathrm{mM} \mathrm{NaCl}, 50 \mathrm{mM}$ Tris-HCl pH 7.5, $10 \%$ glycerol, $50 \mathrm{mM} \mathrm{NaF}, 1 \mathrm{mM} \mathrm{Na}_{3} \mathrm{VO}_{4}$, and a protease-phosphatase inhibitor mixture (Complete mini tablets; Roche, Basel, Switzerland)) was added for $30 \mathrm{~min}$ on ice. Cell debris was discarded by centrifugation at $12,000 \times g$, $4{ }^{\circ} \mathrm{C}$ for $10 \mathrm{~min}$. Protein concentrations were measured using Quick Start ${ }^{\mathrm{TM}}$ Bradford $1 \mathrm{X}$ Dye Reagent (Bio-Rad, CA, USA) and iMark ${ }^{\mathrm{TM}}$ Microplate Reader (Bio-Rad, CA, USA).

The samples were diluted in lysis buffer to obtain equal protein concentration. Then, they were mixed with lithium dodecyl sulfate sample buffer (Invitrogen, Waltham, MA, USA) with $10 \mathrm{mM}$ dithiothreitol (DTT), heated for $10 \mathrm{~min}$ at $70{ }^{\circ} \mathrm{C}$, and separated on $4-12 \%$ Bis-Tris gels with MES running buffer (Invitrogen, Waltham, MA, USA). The gel was then transferred to iBlot gel transfer stacks. Proteins were transferred to the nitrocellulose membrane using the iBlot Dry Blotting System (Invitrogen, Waltham, MA, USA). The finished blot was soaked with 5\% BSA in Tris-buffered saline with 0.05\% Tween-20 and incubated with antibodies diluted to 1:1000 against indicated proteins on a shaker overnight at $4{ }^{\circ} \mathrm{C}$. Super Signal (West Femto Maximum Sensitivity Substrate) (Thermo Fisher Scientific, Rockford, IL, USA) substrate was added to the horseradish peroxidase-conjugated antibodies (Dako Cytomation, Copenhagen, Denmark) stained blot for $3 \mathrm{~min}$ before the luminescence signal was detected using odyssey Fc imager (LI-COR Biosciences, Lincoln, NE, USA) and processed using Image Studio software (LI-COR Biosciences, Lincoln, NE, USA).

\subsection{Statistical Analysis}

All analysis in cellular profiling was performed in the statistical software package R. For statistical analysis and generating figures for viability and apoptosis assay, graph pad prism 9.0.1 (San Diego, CA, USA) was used. Non-linear regression analysis was used to fit the dose-response curves (variable slope model) and calculate absolute IC50 values based 
on concentration. Statistical analysis was performed using one-way ANOVA. Dunnets posthoc analysis was used to correct multiple comparisons when comparing untreated control with treated samples. To compensate for the violation of homogeneity of variances due to unequal sample sizes, the Welch ANOVA test was applied. The significance of the differences is determined if the $p$-value is less than 0.05 .

Author Contributions: Conceptualization, B.J., A.J.F., F.J.A., M.B., S.E. and N.M.; methodology, N.M.; software, N.M.; validation, N.M., F.J.A., A.J.F., M.B., E.N.V. and S.E.; formal analysis, N.M., and F.J.A.; investigation, N.M.; resources, B.J., M.B. and A.J.F.; data curation, N.M., A.J.F. and F.J.A.; writing—original draft preparation, N.M.; writing—review and editing, F.J.A., A.J.F., M.B. and B.J.; visualization, N.M., F.J.A. and A.J.F.; supervision, B.J., M.B., A.J.F. and F.J.A.; project administration, B.J. and A.J.F.; funding acquisition, B.J. and A.J.F. All authors have read and agreed to the published version of the manuscript.

Funding: This research was supported by The Research Council of Norway grant no. 311392 and Coegin Pharma.

Institutional Review Board Statement: Not applicable.

Informed Consent Statement: Not applicable.

Data Availability Statement: The data that support the findings of this study are available in this manuscript and the databases of Jonathan Keat's Lab (www.keatslab.org), CCLE (https://sites. broadinstitute.org/ccle/), Genevestigator (https://genevestigator.com/), and Oncomine (https: //www.oncomine.org/).

Acknowledgments: The authors are grateful to Pegah Abdollahi, Thuy Nguyen, Hanne Hella, Berit Størdal, and Glenn Buene for technical support.

Conflicts of Interest: B.J. and A.J.F. are shareholders of Coegin Pharma. N.M. and F.J.A. are employees of Coegin Pharma. The other authors declare no conflict of interest. The funders had no role in the design of the study, in the collection, analyses, or interpretation of data, in the writing of the manuscript, or in the decision to publish the results.

Sample Availability: Samples of the compounds are available from the authors.

\section{References}

1. Rodriguez-Abreu, D.; Bordoni, A.; Zucca, E. Epidemiology of hematological malignancies. Ann. Oncol. 2007, 18 (Suppl. 1), i3-i8. [CrossRef]

2. Kyle, R.A.; Rajkumar, S.V. Multiple myeloma. Blood 2008, 111, 2962-2972. [CrossRef]

3. Hideshima, T.; Mitsiades, C.; Tonon, G.; Richardson, P.G.; Anderson, K.C. Understanding multiple myeloma pathogenesis in the bone marrow to identify new therapeutic targets. Nat. Rev. Cancer 2007, 7, 585-598. [CrossRef] [PubMed]

4. Palumbo, A.; Anderson, K. Multiple myeloma. N. Engl. J. Med. 2011, 364, 1046-1060. [CrossRef] [PubMed]

5. Eslick, R.; Talaulikar, D. Multiple myeloma: From diagnosis to treatment. Aust. Fam. Phys. 2013, 42, $684-688$.

6. Firth, J. Haematology: Multiple myeloma. Clin. Med. (Lond.) 2019, 19, 58-60. [CrossRef]

7. Wang, D.; Dubois, R.N. Eicosanoids and cancer. Nat. Rev. Cancer 2010, 10, 181-193. [CrossRef]

8. Dennis, E.A.; Cao, J.; Hsu, Y.H.; Magrioti, V.; Kokotos, G. Phospholipase A2 enzymes: Physical structure, biological function, disease implication, chemical inhibition, and therapeutic intervention. Chem. Rev. 2011, 111, 6130-6185. [CrossRef] [PubMed]

9. Ghosh, M.; Tucker, D.E.; Burchett, S.A.; Leslie, C.C. Properties of the Group IV phospholipase A2 family. Prog. Lipid Res. 2006, 45, 487-510. [CrossRef]

10. Chen, L.; Fu, H.; Luo, Y.; Chen, L.; Cheng, R.; Zhang, N.; Guo, H. cPLA2 $\alpha$ mediates TGF- $\beta$-induced epithelial-mesenchymal transition in breast cancer through PI3k/Akt signaling. Cell Death Dis. 2017, 8, e2728. [CrossRef]

11. Fu, H.; He, Y.; Qi, L.; Chen, L.; Luo, Y.; Chen, L.; Li, Y.; Zhang, N.; Guo, H. cPLA2 $\alpha$ activates PI3K/AKT and inhibits Smad2/3 during epithelial-mesenchymal transition of hepatocellular carcinoma cells. Cancer Lett. 2017, 403, 260-270. [CrossRef] [PubMed]

12. Xu, H.; Sun, Y.; Zeng, L.; Li, Y.; Hu, S.; He, S.; Chen, H.; Zou, Q.; Luo, B. Inhibition of cytosolic phospholipase A2 alpha increases chemosensitivity in cervical carcinoma through suppressing $\beta$-catenin signaling. Cancer Biol. Ther. 2019, 20, 912-921. [CrossRef]

13. Patel, M.I.; Singh, J.; Niknami, M.; Kurek, C.; Yao, M.; Lu, S.; Maclean, F.; King, N.J.; Gelb, M.H.; Scott, K.F.; et al. Cytosolic phospholipase A2-alpha: A potential therapeutic target for prostate cancer. Clin. Cancer Res. 2008, 14, 8070-8079. [CrossRef] [PubMed]

14. Xin, C.; Chu, L.; Zhang, L.; Geng, D.; Wang, Y.; Sun, D.; Sui, P.; Zhao, X.; Gong, Z.; Sui, M.; et al. Expression of Cytosolic Phospholipase A2 (cPLA2)-Arachidonic Acid (AA)-Cyclooxygenase-2 (COX-2) Pathway Factors in Lung Cancer Patients and Its Implication in Lung Cancer Early Detection and Prognosis. Med. Sci. Monit. 2019, 25, 5543-5551. [CrossRef] 
15. Bai, H.; Zhou, M.; Zeng, M.; Han, L. PLA2G4A Is a Potential Biomarker Predicting Shorter Overall Survival in Patients with Non-M3/NPM1 Wildtype Acute Myeloid Leukemia. DNA Cell Biol. 2020, 39, 700-708. [CrossRef]

16. Runarsson, G.; Feltenmark, S.; Forsell, P.K.; Sjöberg, J.; Björkholm, M.; Claesson, H.E. The expression of cytosolic phospholipase A2 and biosynthesis of leukotriene B4 in acute myeloid leukemia cells. Eur. J. Haematol. 2007, 79, 468-476. [CrossRef] [PubMed]

17. Guriec, N.; Le Jossic-Corcos, C.; Simon, B.; Ianotto, J.C.; Tempescul, A.; Dréano, Y.; Salaün, J.P.; Berthou, C.; Corcos, L. The arachidonic acid-LTB4-BLT2 pathway enhances human B-CLL aggressiveness. Biochim. Biophys. Acta 2014, 1842, $2096-2105$. [CrossRef] [PubMed]

18. Chitale, D.; Gong, Y.; Taylor, B.S.; Broderick, S.; Brennan, C.; Somwar, R.; Golas, B.; Wang, L.; Motoi, N.; Szoke, J.; et al. An integrated genomic analysis of lung cancer reveals loss of DUSP4 in EGFR-mutant tumors. Oncogene 2009, 28, 2773-2783. [CrossRef]

19. Gravendeel, L.A.; Kouwenhoven, M.C.; Gevaert, O.; de Rooi, J.J.; Stubbs, A.P.; Duijm, J.E.; Daemen, A.; Bleeker, F.E.; Bralten, L.B.; Kloosterhof, N.K.; et al. Intrinsic gene expression profiles of gliomas are a better predictor of survival than histology. Cancer Res. 2009, 69, 9065-9072. [CrossRef] [PubMed]

20. Clarke, C.; Madden, S.F.; Doolan, P.; Aherne, S.T.; Joyce, H.; O’Driscoll, L.; Gallagher, W.M.; Hennessy, B.T.; Moriarty, M.; Crown, J.; et al. Correlating transcriptional networks to breast cancer survival: A large-scale coexpression analysis. Carcinogenesis 2013, 34, 2300-2308. [CrossRef] [PubMed]

21. Zhan, F.; Huang, Y.; Colla, S.; Stewart, J.P.; Hanamura, I.; Gupta, S.; Epstein, J.; Yaccoby, S.; Sawyer, J.; Burington, B.; et al. The molecular classification of multiple myeloma. Blood 2006, 108, 2020-2028. [CrossRef] [PubMed]

22. Minn, A.J.; Gupta, G.P.; Padua, D.; Bos, P.; Nguyen, D.X.; Nuyten, D.; Kreike, B.; Zhang, Y.; Wang, Y.; Ishwaran, H.; et al. Lung metastasis genes couple breast tumor size and metastatic spread. Proc. Natl. Acad. Sci. USA 2007, 104, 6740-6745. [CrossRef]

23. Magrioti, V.; Kokotos, G. Phospholipase A2 inhibitors for the treatment of inflammatory diseases: A patent review (2010-present). Expert Opin. Ther. Pat. 2013, 23, 333-344. [CrossRef] [PubMed]

24. Linkous, A.; Geng, L.; Lyshchik, A.; Hallahan, D.E.; Yazlovitskaya, E.M. Cytosolic phospholipase A2: Targeting cancer through the tumor vasculature. Clin. Cancer Res. 2009, 15, 1635-1644. [CrossRef]

25. Linkous, A.G.; Yazlovitskaya, E.M.; Hallahan, D.E. Cytosolic phospholipase A2 and lysophospholipids in tumor angiogenesis. J. Natl. Cancer Inst. 2010, 102, 1398-1412. [CrossRef] [PubMed]

26. Thotala, D.; Craft, J.M.; Ferraro, D.J.; Kotipatruni, R.P.; Bhave, S.R.; Jaboin, J.J.; Hallahan, D.E. Cytosolic phospholipaseA2 inhibition with PLA-695 radiosensitizes tumors in lung cancer animal models. PLoS ONE 2013, 8, e69688. [CrossRef]

27. Zhang, W.; Wang, X.; Zhang, L.; Geng, D.; Wang, Y.; Sun, D.; Sui, P.; Zhao, X.; Xin, C.; Jiang, J.; et al. Inhibition of PLA2G4A Reduces the Expression of Lung Cancer-Related Cytokines. DNA Cell Biol. 2018, 37, 1076-1081. [CrossRef] [PubMed]

28. Ashcroft, F.J.; Mahammad, N.; Midtun Flatekvål, H.; Jullumstrø Feuerherm, A.; Johansen, B. cPLA(2) $\alpha$ Enzyme Inhibition Attenuates Inflammation and Keratinocyte Proliferation. Biomolecules 2020, 10, 1402. [CrossRef]

29. Huwiler, A.; Feuerherm, A.J.; Sakem, B.; Pastukhov, O.; Filipenko, I.; Nguyen, T.; Johansen, B. The w3-polyunsaturated fatty acid derivatives AVX001 and AVX002 directly inhibit cytosolic phospholipase A(2) and suppress PGE(2) formation in mesangial cells. Br. J. Pharmacol. 2012, 167, 1691-1701. [CrossRef]

30. Sommerfelt, R.M.; Feuerherm, A.J.; Skuland, T.; Johansen, B. Cytosolic phospholipase A2 modulates TLR2 signaling in synoviocytes. PLoS ONE 2015, 10, e0119088. [CrossRef] [PubMed]

31. Sommerfelt, R.M.; Feuerherm, A.J.; Jones, K.; Johansen, B. Cytosolic phospholipase A2 regulates TNF-induced production of joint destructive effectors in synoviocytes. PLoS ONE 2013, 8, e83555. [CrossRef] [PubMed]

32. Omland, S.H.; Habicht, A.; Damsbo, P.; Wilms, J.; Johansen, B.; Gniadecki, R. A randomized, double-blind, placebo-controlled, dose-escalation first-in-man study (phase 0) to assess the safety and efficacy of topical cytosolic phospholipase A2 inhibitor, AVX001, in patients with mild to moderate plaque psoriasis. J. Eur. Acad. Dermatol. Venereol. 2017, 31, 1161-1167. [CrossRef]

33. Feuerherm, A.J.; Dennis, E.A.; Johansen, B. Cytosolic group IVA phospholipase A2 inhibitors, AVX001 and AVX002, ameliorate collagen-induced arthritis. Arthritis Res. Ther. 2019, 21, 29. [CrossRef] [PubMed]

34. Kim, E.; Tunset, H.M.; Cebulla, J.; Vettukattil, R.; Helgesen, H.; Feuerherm, A.J.; Engebråten, O.; Mælandsmo, G.M.; Johansen, B.; Moestue, S.A. Anti-vascular effects of the cytosolic phospholipase A2 inhibitor AVX235 in a patient-derived basal-like breast cancer model. BMC Cancer 2016, 16, 191. [CrossRef] [PubMed]

35. Tunset, H.M.; Feuerherm, A.J.; Selvik, L.M.; Johansen, B.; Moestue, S.A. Cytosolic Phospholipase A2 Alpha Regulates TLR Signaling and Migration in Metastatic 4T1 Cells. Int. J. Mol. Sci. 2019, 20, 4800. [CrossRef] [PubMed]

36. Johansen, B.; Sanderberg, M.; Aukrust, I.R.; Kokotos, G.; Barbayianni, E. Antiiflammatory and antitumor 2-oxothiazoles and 2-oxothiophenes compounds. US Patent Application No. 14/764,509, 31 December 2015.

37. Mahammad, N.; Ashcroft, F.J.; Feuerherm, A.J.; Kokotos, G.; Gjertsen, B.T.; Dennis, E.A.; Johansen, B. AVX420, a novel cPLA2 $\alpha$ inhibitor targeting hematological cancers. Manuscript in preparation.

38. Zimmermann, P.; Hennig, L.; Gruissem, W. Gene-expression analysis and network discovery using Genevestigator. Trends Plant Sci. 2005, 10, 407-409. [CrossRef] [PubMed]

39. Barretina, J.; Caponigro, G.; Stransky, N.; Venkatesan, K.; Margolin, A.A.; Kim, S.; Wilson, C.J.; Lehár, J.; Kryukov, G.V.; Sonkin, D.; et al. The Cancer Cell Line Encyclopedia enables predictive modelling of anticancer drug sensitivity. Nature 2012, 483, 603-607. [CrossRef] [PubMed] 
40. Rhodes, D.R.; Yu, J.; Shanker, K.; Deshpande, N.; Varambally, R.; Ghosh, D.; Barrette, T.; Pandey, A.; Chinnaiyan, A.M. ONCOMINE: A cancer microarray database and integrated data-mining platform. Neoplasia 2004, 6, 1-6. [CrossRef]

41. Chaudhry, P.; Singh, M.; Parent, S.; Asselin, E. Prostate apoptosis response 4 (Par-4), a novel substrate of caspase-3 during apoptosis activation. Mol. Cell Biol. 2012, 32, 826-839. [CrossRef]

42. Elsaadi, S.; Steiro, I.; Abdollahi, P.; Vandsemb, E.N.; Yang, R.; Slørdahl, T.S.; Rø, T.B.; Menu, E.; Sponaas, A.M.; Børset, M. Targeting phosphoglycerate dehydrogenase in multiple myeloma. Exp Hematol. Oncol. 2021, 10, 3. [CrossRef] [PubMed]

43. Sayan, B.S.; Sayan, A.E.; Yang, A.L.; Aqeilan, R.I.; Candi, E.; Cohen, G.M.; Knight, R.A.; Croce, C.M.; Melino, G. Cleavage of the transactivation-inhibitory domain of $\mathrm{p} 63$ by caspases enhances apoptosis. Proc. Natl. Acad. Sci. USA 2007, 104, 10871-10876. [CrossRef] [PubMed]

44. El-Hamid, E.S.A.; Gamal-Eldeen, A.M.; Sharaf Eldeen, A.M. Liposome-coated nano doxorubicin induces apoptosis on oral squamous cell carcinoma CAL-27 cells. Arch Oral. Biol. 2019, 103, 47-54. [CrossRef]

45. Tacar, O.; Sriamornsak, P.; Dass, C.R. Doxorubicin: An update on anticancer molecular action, toxicity and novel drug delivery systems. J. Pharm. Pharmacol. 2013, 65, 157-170. [CrossRef]

46. Vu, M.; Kassouf, N.; Ofili, R.; Lund, T.; Bell, C.; Appiah, S. Doxorubicin selectively induces apoptosis through the inhibition of a novel isoform of Bcl-2 in acute myeloid leukaemia MOLM-13 cells with reduced Beclin 1 expression. Int. J. Oncol. 2020, 57, 113-121. [CrossRef]

47. Heasley, L.E.; Thaler, S.; Nicks, M.; Price, B.; Skorecki, K.; Nemenoff, R.A. Induction of cytosolic phospholipase A2 by oncogenic Ras in human non-small cell lung cancer. J. Biol. Chem. 1997, 272, 14501-14504. [CrossRef]

48. Wu, T.; Han, C.; Lunz, J.G., 3rd; Michalopoulos, G.; Shelhamer, J.H.; Demetris, A.J. Involvement of 85-kd cytosolic phospholipase $\mathrm{A}(2)$ and cyclooxygenase-2 in the proliferation of human cholangiocarcinoma cells. Hepatology 2002, 36, 363-373. [CrossRef] [PubMed]

49. Soydan, A.S.; Tavares, I.A.; Weech, P.K.; Temblay, N.M.; Bennett, A. High molecular weight phospholipase A2 and fatty acids in human colon tumours and associated normal tissue. Eur. J. Cancer 1996, 32a, 1781-1787. [CrossRef]

50. Naini, S.M.; Choukroun, G.J.; Ryan, J.R.; Hentschel, D.M.; Shah, J.V.; Bonventre, J.V. Cytosolic phospholipase A2 $\alpha$ regulates G1 progression through modulating FOXO1 activity. Faseb J. 2016, 30, 1155-1170. [CrossRef]

51. Kisslov, L.; Hadad, N.; Rosengraten, M.; Levy, R. HT-29 human colon cancer cell proliferation is regulated by cytosolic phospholipase $\mathrm{A}(2) \alpha$ dependent PGE(2)via both PKA and PKB pathways. Biochim. Biophys. Acta 2012, 1821, 1224-1234. [CrossRef]

52. Han, C.; Bowen, W.C.; Li, G.; Demetris, A.J.; Michalopoulos, G.K.; Wu, T. Cytosolic phospholipase A2alpha and peroxisome proliferator-activated receptor gamma signaling pathway counteracts transforming growth factor beta-mediated inhibition of primary and transformed hepatocyte growth. Hepatology 2010, 52, 644-655. [CrossRef]

53. Goodwin, A.M. In vitro assays of angiogenesis for assessment of angiogenic and anti-angiogenic agents. Microvasc Res. 2007, 74, 172-183. [CrossRef]

54. Zeeshan, R.; Mutahir, Z. Cancer metastasis-Tricks of the trade. Bosn J. Basic Med. Sci. 2017, 17, 172-182. [CrossRef]

55. Clodi, K.; Kliche, K.O.; Zhao, S.; Weidner, D.; Schenk, T.; Consoli, U.; Jiang, S.; Snell, V.; Andreeff, M. Cell-surface exposure of phosphatidylserine correlates with the stage of fludarabine-induced apoptosis in chronic lymphocytic leukemia and expression of apoptosis-regulating genes. Cytometry 2000, 40, 19-25. [CrossRef]

56. Nagata, S.; Suzuki, J.; Segawa, K.; Fujii, T. Exposure of phosphatidylserine on the cell surface. Cell Death Differ. 2016, 23, 952-961. [CrossRef] [PubMed]

57. van den Eijnde, S.M.; Boshart, L.; Baehrecke, E.H.; De Zeeuw, C.I.; Reutelingsperger, C.P.; Vermeij-Keers, C. Cell surface exposure of phosphatidylserine during apoptosis is phylogenetically conserved. Apoptosis 1998, 3, 9-16. [CrossRef]

58. Duarte, R.A.; Mello, E.R.; Araki, C.; Bolzani Vda, S.; Siqueira e Silva, D.H.; Regasini, L.O.; Silva, T.G.; de Morais, M.C.; Ximenes, V.F.; Soares, C.P. Alkaloids extracted from Pterogyne nitens induce apoptosis in malignant breast cell line. Tumour. Biol. 2010, 31, 513-522. [CrossRef]

59. Habiba, K.; Encarnacion-Rosado, J.; Garcia-Pabon, K.; Villalobos-Santos, J.C.; Makarov, V.I.; Avalos, J.A.; Weiner, B.R.; Morell, G. Improving cytotoxicity against cancer cells by chemo-photodynamic combined modalities using silver-graphene quantum dots nanocomposites. Int. J. Nanomed. 2016, 11, 107-119. [CrossRef]

60. Sačková, V.; Kuliková, L.; Kello, M.; Uhrinová, I.; Fedoročko, P. Enhanced antiproliferative and apoptotic response of HT-29 adenocarcinoma cells to combination of photoactivated hypericin and farnesyltransferase inhibitor manumycin A. Int. J. Mol. Sci. 2011, 12, 8388-8405. [CrossRef]

61. Sundquist, T.; Moravec, R.; Niles, A.; O’Brien, M.; Riss, T. Timing Your Apoptosis Assays. Cell Notes 2016, 16, 18-21.

62. Anthonsen, M.W.; Solhaug, A.; Johansen, B. Functional coupling between secretory and cytosolic phospholipase A2 modulates tumor necrosis factor-alpha- and interleukin-1beta-induced NF-kappa B activation. J. Biol. Chem. 2001, 276, 30527-30536. [CrossRef] [PubMed]

63. George, R.J.; Sturmoski, M.A.; Anant, S.; Houchen, C.W. EP4 mediates PGE2 dependent cell survival through the PI3 kinase/AKT pathway. Prostaglandins Other Lipid Mediat. 2007, 83, 112-120. [CrossRef] 
64. Holmeide, A.K.; Skattebol, L. Syntheses of some polyunsaturated trifluoromethyl ketones as potential phospholipase A(2) inhibitors. J. Chem. Soc. Perkin. Trans. 2000, 1, 2271-2276. [CrossRef]

65. Kokotos, G.; Feuerherm, A.J.; Barbayianni, E.; Shah, I.; Sæther, M.; Magrioti, V.; Nguyen, T.; Constantinou-Kokotou, V.; Dennis, E.A.; Johansen, B. Inhibition of group IVA cytosolic phospholipase A2 by thiazolyl ketones in vitro, ex vivo, and in vivo. J. Med. Chem. 2014, 57, 7523-7535. [CrossRef] 